\title{
KEMAMPUAN ANALISIS TERHADAP NILAI MODUL BIOFISIKA MAHASISWA ANGKATAN 2013 FAKULTAS KEDOKTERAN UNIVERSITAS SAM RATULANGI
}

\author{
${ }^{1}$ Randy V.S. Kindangen \\ ${ }^{2}$ Damajanty H.C. Pangemanan \\ ${ }^{2}$ Joice N.A. Engka \\ ${ }^{1}$ Kandidat Skripsi Fakultas Kedokteran Universitas Sam Ratulangi Manado \\ ${ }^{2}$ Bagian Fisiologi Fakultas Kedokteran Universitas Sam Ratulangi Manado \\ Email: randykindangen@gmail.com
}

\begin{abstract}
Analytical skill is the ability to visualize, express, and solve problems or concepts both simple and complex and make the right decisions. Studies showed positive effects of analytical skill onacademic achievement and learning process. This study aims to determine the effect of analytical skills on academic achievement using Biophysics module grade as a reference. The study is an observational analytic with cross-sectional study method that was conducted to students ofFaculty of Medicine of Sam Ratulangi University. Data of analytical skill were obtained by using Intelligence Structure Test (IST). The data then analyzed with Kendall's tau b correlation test. Statistical test of Kendall's tau b shows the correlation coefficient of 0.120 and $p=0.206(>0.05)$, which means there is no significant effect of analytical skill on Biophysics module score.
\end{abstract}

Keywords: Analytical skill, biophysics module, academic achievement

\begin{abstract}
Abstrak: Kemampuan analisis adalah kemampuan untuk memvisualisasikan, mengekspresikan, dan memecahkan masalah atau konsep baik yang kompleks maupun sederhana dan membuat keputusan yang tepat. Terdapat penelitian yang menunjukkan pengaruh positif kemampuan analisis terhadapprestasi belajar dan proses belajar. Penelitian ini bertujuan untuk mengetahui pengaruh kemampuan analisis terhadap prestasi belajar dengan menggunakan nilai modul Biofisika sebagai acuan.Penelitian bersifat observasional analitik dengan metode penelitian potong lintang yang dilakukan pada mahasiswa Fakultas Kedokteran Universitas Sam Ratulangi.Data kemampuan analisis diperoleh dengan menggunakan Intelligenz Structure Test (IST). Data yang didapat kemudian dianalisa dengan uji korelasi Kendall's tau b. Uji statistik Kendall's tau $b$ menunjukkan correlation coefficientsebesar 0,120 dan $\mathrm{p}=0,206(>0,05)$ yang berarti tidak terdapat pengaruh yang signifikan oleh kemampuan analisis terhadap nilai modul Biofisika.
\end{abstract}

Kata Kunci: Kemampuan analisis, modul biofisika, prestasi belajar

Analisis menurut Strauss (2008) mempunyai makna yang dapat ditunjukan oleh dua fitur yang koheren, yaitu mengidentifikasi dan membedakan.Identifikasi dalam hal ini mempunyai makna yaitu beberapa fitur yang bersatu.Makna dari indentifikasi tersebut bersifat universal dan tidak berdiri sendiri sehingga dikatakan bahwa sintesis (mengidentifikasi) tidak bertentangan dengan analisis namun bertautan dengan distinguishing (membedakan) sebagai makna analisis. $^{1} \quad$ Kemampuan analisis adalah kemampuan untuk memvisualisasikan, mengekspresikan, dan memecahkan masalah atau konsep baik yang kompleks maupun sederhana dan membuat keputusan yang tepat berdasarkan informasi yang tersedia. Berbeda dengan pengetahuan yang 
dipelajari lewat kuliah, kemampuan analisis dipelajari dengan melakukan dan dari pengalaman. $^{2}$

Kemampuan analisis yang cukup diperlukan oleh mahasiswa untuk menanggapi standar pendidikan pada masa sekarang seperti yang disampaikan Mellow. ${ }^{3}$ Pembelajaran dengan metode problem solving pada kurikulumyang digunakan dalam institusi pendidikan dokter merupakan salah satu cara untuk melatih penggunaan kemampuan analisis dalam proses belajar, dimana penelitian oleh Zhang, ${ }^{4}$ menunjukkan hasil yang signifikan dalam meningkatkan proses belajar yang efektif.Suatu penelitian yang dilakukan oleh Husain tidak menunjukkan adanya hubungan antara kemampuan analisis dengan nilai akademik. Penelitian oleh Deary menunjukkan hasil bahwa kemampuan kognitif (kemampuan analisis yang merupakan salah satunya) memiliki kontribusi yang besar terhadap kemampuan belajar secara umum. ${ }^{5}$

Berdasarkan teori yang ada, kemampuan analisis dibutuhkan untuk dapat mengerjakan aktivitas yang memerlukan kemampuan berpikir kritis seperti dalam proses belajar secara efektif. Penelitian ini dilakukan untuk melihat pengaruh kemampuan analisis terhadap prestasi belajar.

\section{METODE PENELITIAN}

Penelitian bersifat observasional analitik dengan menggunakan metode penelitianpotong lintang. Penelitian dilakukan pada 100 orang mahasiswa Fakultas Kedokteran yang dipilih secara acak. Nilai kemampuan analisis subyek penilitian merupakan hasil paduan dari nilai Analogien (AN), Zahlen Reihen (ZR), Form Auswahl (FA), Wurfel Aufgaben (WA) yang merupakan subtes dari Intelligenz Structure Test (IST). ${ }^{6}$ IST merupakan tes inteligensi yang dibagi menjadi 9 subtes untuk menilai berbagai kemampuan mencakup kemampuan verbal, numerik, dan figural-spasial ${ }^{7}$. Modul Biofisika adalah salah satu modul yang diterima subjek yang digunakan untuk melihat hasil penggunaan kemampuan analisis dalam belajar. Analisis korelasi
Kendall's tau $b$ digunakan untuk melihat korelasi antara kedua variabel.

\section{HASIL PENELITIAN}

Pada penelitian ini digunakan subyek penelitian sebanyak 100 orang mahasiswa yang mengikuti ujian modul Biofisika.

Distribusi nilai kemampuan analisis terhadap 100 responden yang diteliti didapatkan nilai kemampuan analisis dalam kategori baik sebesar 8\% atau sebanyak 8 orang, nilai kemapuan analisis cukup sebesar 58\% atau sebanyak 58 orang, nilai kemampuan analisis sedang sebesar 34\% atau sebanyak 34 orang (Tabel 1).

Tabel 1. Distribusi nilai kemampuan analisis berdasarkan kategori ${ }^{8}$

\begin{tabular}{cccc}
\hline Kategori & $\begin{array}{c}\text { Nilai } \\
\text { Kemampuan } \\
\text { Analisis }\end{array}$ & n & \% \\
\hline Kurang Sekali & $\leq 70$ & 0 & $0 \%$ \\
Kurang & $71-84$ & 0 & $0 \%$ \\
Sedang & $85-99$ & 34 & $34 \%$ \\
Cukup & $100-114$ & 58 & $58 \%$ \\
Baik & $115-129$ & 8 & $8 \%$ \\
Baik Sekali & $>130$ & 0 & $0 \%$ \\
Total & & 100 & $100 \%$ \\
\hline
\end{tabular}

Berdasarkan jenis kelamin diketahui, responden laki-laki berjumlah 50 orang (50\%) dan perempuan berjumlah 50 orang (50\%) (Tabel 2). Rerata nilai kemampuan analisis responden laki-laki lebih tinggi dibandingkan rerata responden perempuan.Pada penelitian ini tidak dilakukan uji statistik untuk melihat korelasi antara jenis kelamin dengan kemampuan analisis.

Tabel 2. Distribusi nilai kemampuan analisis berdasarkan jenis kelamin

\begin{tabular}{lccc}
\hline $\begin{array}{l}\text { Jenis } \\
\text { Kelamin }\end{array}$ & n & \% & $\begin{array}{c}\text { Rerata Nilai } \\
\text { Kemampuan } \\
\text { Analisis }\end{array}$ \\
\hline Laki-laki & 50 & $50 \%$ & 105,32 \\
Perempuan & 50 & $50 \%$ & 100,04 \\
Total & 100 & $100 \%$ & 102,68 \\
\hline
\end{tabular}


Kindangen, Pangemananan, Engka; Kemampuan Analisis terhadap Nilai Modul Fisika...

Distribusi nilai ujian modul Biofisika pada 100 responden yang diteliti didapatkan nilai ujian modul Biofisika A sebesar 9\% atau sebanyak 9 orang, nilai ujian modul biofisika B dengan distribusi terbesar yaitu sebesar 81\%, nilai ujian modul Biofisika C sebesar 9\%, nilai ujian modul Biofisika D sebesar 0\%, dan nilai ujian modul Biofisika E sebesar 1\% (Tabel 3).

Tabel 3. Distribusi nilai ujian modul Biofisika responden penelitian

\begin{tabular}{|c|c|c|}
\hline $\begin{array}{c}\text { Nilai Ujian Modul } \\
\text { Biofisika }\end{array}$ & $\mathbf{n}$ & $\%$ \\
\hline $\mathrm{A}$ & 9 & $9 \%$ \\
\hline B & 81 & $81 \%$ \\
\hline $\mathrm{C}$ & 9 & $0 \%$ \\
\hline $\mathrm{D}$ & 0 & $0 \%$ \\
\hline E & 1 & $1 \%$ \\
\hline Total & 100 & $100 \%$ \\
\hline
\end{tabular}

Berdasarkan hasil uji Kendall's tau $b$ didapatkan nilai $\tau_{\mathrm{B}}=0,120$ yang menunjukan kekuatan korelasi antara nilai modul Bio-fisika dan kemampuan analisis yang kurang kuat, sedangkan nilai $\mathrm{p}=0,206$ $(>0,05)$ menunjukan tidak adanya pengaruh kemam-puan analisis terhadap nilai modul Biofisika yang bermakna pada mahasiswa semester 1 Fakultas Kedokteran program studi pendi-dikan dokter Universitas Sam Ratulangi.

\section{BAHASAN}

Hasil penelitian menunjukan sebagian besar responden memiliki kemampuan analisis dalam kategori cukup yaitu sebesar 58\%. Hasil penelitian ini memiliki hasil yang sama dengan penelitian yang dilakukan oleh Husain H dkk (2012) yang meneliti tentang kemampuan analisis pada Electrical and Engineering Students University Kebangsaan Malaysia. Penelitian tersebut menunjukan sebagian besar mahasiswa memiliki kemampuan analisis cukup. ${ }^{9}$

Berdasarkan jenis kelamin, responden laki-laki memiliki nilai kemampuan analisis yang lebih tinggi dari responden perempuan. Menurut Reilly D(2012), ada perbedaan kemampuan kognitif antara laki-laki dan perempuan yang dipengaruhi oleh faktor ekonomi, kesetaraan gender, dan kebudayaan dari tiap negara, namun perbedaan tersebut hanya terdapat pada aspek-aspek tertentu dari kemampuan kognitif dan tidak mempengaruhi kemampuan analisis. ${ }^{10}$ Kemungkinan hasil ini disebabkan oleh karena pada waktu pelaksaan tes inteligensi, responden perempuan telah mengikuti tes daya tahan terhadap stres yaitu tes Pauli dimana diperlukan adanya beban stres pada responden sebelum mengikuti tes tersebut. Berbeda dengan responden jenis kelamin laki-laki, tes inteligensi dilakukan sebelum tes Pauli sehingga beban stres yang ditanggung lebih ringan dibandingkan responden dengan jenis kelamin perempuan.

Nilai ujian modul Biofisika menunjukkan sebagian besar responden penelitian memiliki nilai $\mathrm{B}$, yaitu sekitar 81 orang. Nilai modul Biofisika pada mahasiswa semester 1 yang berjumlah 259 orang juga menunjukan bahwa sebesar 78\% atau 202 mahasiswa yang mendapat nilai $B$, sedangkan hanya sebesar 16,3\% mahasiswa tidak lulus ujian. Hasil ini menunjukkan sebagian besar mahasiswa semester 1 memiliki prestasi akademik yang tinggi.

Hasil penelitian dengan menggunakan uji Kendall's tau b menunjukan nilai coefficient correlation 0,120 atau dalam simbol $\tau_{\mathrm{B}}=0,120$. Untuk menentukan tidak adanya pengaruh kemampuan analisis terhadap nilai modul Biofisika, peneliti menguji $\mathrm{H}_{0}$ dimana $\tau_{\mathrm{B}}=0$ dan $\mathrm{H}_{1}$ dimana kedua variabel berkorelasi dan $\tau_{\mathrm{B}} \neq 0$ dengan demikian didapatkan kekuatan korelasi variabel yang didapatkan kurang kuat (semakin dekat nilai correlationcoefficient ke angka +1 atau -1 maka semakin kuat kekuatan korelasi). Berdasarkan hasil penelitian juga didapatkan nilai $\mathrm{p}=0,206$, sehingga $\mathrm{H}_{0}$ tidak dibantah sebab variabel dinyatakan tidak berkorelasi pada $\mathrm{p}>0,05$ (tidak signifikan). Hasil tersebut sesuai dengan penilitian yang dilakukan Husain $\mathrm{H}$ (2012) pada mahasiswa Universiti Kebangsaan Malaysia, dimana sebagian besar hasil kemampuan analisis menunjukkan pada tingkat Sedang, walaupun mahasiswa 
tersebut memiliki prestasi akademik yang tinggi. Berbeda dengan hasil penelitian Deary IJ (2007) yang menunjukan korelasi yang kuat antara kemampuan kognitif secara umum (kemampuan analisis merupakan salah satu kemampuan kognitif) dengan prestasi belajar. Penelitian oleh Deary IJ yang dilakukan pada 70.000 anak yang bertujuan untuk meneliti pengaruh kemampuan kognitif (khususnya inteligensi) pada umur 11 tahun terhadap prestasi belajar pada umur 16 tahun. Hasil menunjukkan korelasi sebesar 0,81 (kekuatan korelasi kuat) yang berarti kemampuan kognitif memiliki kontribusi yang besar terhadap kemampuan belajar secara umum. ${ }^{5}$

\section{SIMPULAN}

Penelitian ini menggunakan Intelligenz Structure Test (IST) untuk mengukur kemampuan analisis pada mahasiswa angkatan 2013.Hasil uji statistik menunjukkan $\mathrm{p}>0,05$ sehingga $\mathrm{H}_{0}$ diterima dan $\mathrm{H}_{1}$ ditolak dan menunjukkan bahwa kemampuan analisis tidak mempunyai pengaruh terhadap nilai modul Biofisika walaupun sebagian besar nilai kedua variabel menunjukan jumlah diatas rata-rata pada mahasiswa.

\section{DAFTAR PUSTAKA}

1. Strauss D F M. Reflections on the nature of analysis and some analytical skills. SAJHE. 2008;22(5):1070-87.
2. Heuer RJ. Psychology of Intelligence Analysis. Center for the Study of Intelligence, Central Intelligence Agency. 1999.

3. Mellow GO, Woolis DD. Teetering between eras: higher education in a global, knowledge networked world. On the Horizon 2010.18(4).308-319.

4. Zhang Z, Liu W, Han J, Guo S, Wu Y. A trial of patient-oriented problem-solving system for immunology teaching in China: a comparison with dialectic lectures. BMC Medical Education. 2013;13(11).

5. Deary IJ, Strand S, Smith P, Fernandes C. Intelligence and educational achievement. Intelligence. 2008;35(1):13-21.

6. Liepman D, Beauducel A, Brocke B, Horn S. Intelligence Structure Test. Oxford. University of Fribourg. Tersedia dalam:

http://www.unifr.ch/ztd/HTS/inftest/WEBInformationssystem/en/4en001/e26fc99dd0 9a4acc98edd5dae56b0e94/hb.htm (diakses tanggal 27 Oktober 2013).

7. Urbina S. Essentials of Psychological Testing. Hoboken: Wiley; 2004.

8. Groth-Marnat G. Handbook of Psychological Assessment (4 ${ }^{\text {th }}$ ed). Hoboken: Wiley; 2009

9. Husain H, Mokri SS, Hussain A, Samad SA, Majid RA. The Level of Critical and Analysis Thinking Skills among Electrical and Electronics Engineering Students, UKM. Asian Social Science. 2012;8(16):80-7

10. Reilly D. Gender, Culture, and Sex-Typed Cognitive Abilities. PLoS One. 2012;7(7). 